\title{
INROADS ON THE NECESSITY FOR A CONSUMMATED PURCHASE OR SALE UNDER RULE 10b-5
}

\begin{abstract}
The traditional application of rule 10b-5 has required that there be fraud in connection with the purchase or sale of $a$ security. While the Birnbaum rule that a plaintiff be an actual purchaser or seller has been debilitated and the definition of "purchase or sale" considerably expanded, the necessity for some consummated transaction in securities has remained effectively unchallenged. This note explores the manner in which the "in connection with" language of 10b-5 may be extended to encompass securities frauds in situations involving no consummated purchase or sale transaction.
\end{abstract}

Rule 10b-5, promulgated by the Securities and Exchange Commission under the authorization of section $10(\mathrm{~b})$ of the Securities Exchange Act of $1934,{ }^{2}$ proscribes fraud in connection with the purchase or sale of securities. Civil claimants ${ }^{3}$ under $10 \mathrm{~b}-5$, however, have not been subjected to a rigid adherence to the

' 17 C.F.R. $\$ 240.10$ b-5 (1967) reads as follows: "It shall be unlawful for any person, directly or indirectly, by the use of any means or instrumentality of interstate commerce, or of the mails or of any facility of any national securities exchange, (a) To employ any device, scheme, or artifice to defraud, (b) To make any untrue statement of a material fact or to omit to state a material fact necessary in order to make the statements made, in the light of the circumstances under which they were made, not misleading, or (c) To engage in an act, practice, or course of business which operates or would operate as a fraud or deceit upon any person, in connection with the purchase or sale of any security."

215 U.S.C. \& 78j(b) (1964) reads as follows: "It shall be unlawful for any person, directly or indirectly, by the use of any means or instrumentality of interstate commerce or of the mails, or of any facility of any national securities exchange- . . . (b) To use or employ, in connection with the purchase or sale of any security registered on a national securities exchange or any security not so registered, any manipulative or deceptive device or contrivance in contravention of such rules and regulations as the Commission may prescribe as necessary or appropriate in the public interest or for the protection of investors."

3 Rule 10b-5 did not expressly provide a civil remedy, but in Kardon v. Nat'l Gypsum Co., 69 F. Supp. 512 (E.D. Pa. 1946), the court recognized an implied civil remedy. The court based its ruling upon the tort theory that a statute extends a cause of action to those whose interests it was passed to protect. Restatement (SeCOND) of ToRTs $\S 286$ (1964). Section 17 of the Securities Act of 1933,15 U.S.C. $\$ 77 \mathrm{q}$, is virtually identical in language with Rule 10b-5 except that it only applies to misdeeds in connection with the sale of securities. Since section 17(a) expressly provides for civil liability, recognition of the right to 
common law elements of fraud.4 Depending on the policy sought to be protected, ${ }^{5}$ the courts, to varying degrees, have emphasized or minimized such traditional fraud requirements as privity, ${ }^{6}$ scienter, ${ }^{7}$ and reliance. ${ }^{8}$ Certain restraints, however, have been imposed on $10 \mathrm{~b}-5$ claimants. One of the most long-lived of these limitations was established in Birnbaum v. Newport Steel Corp., ${ }^{9}$ in which the Second Circuit ruled that the claimant must be a "defrauded purchaser or seller" 10 in order to maintain his action under 10b-5. Closely related to the Birnbaum purchaser-seller doctrine, but distinct therefrom, is the question of whether a consummated purchase or sale is a prerequisite for $10 b-5$ relief. This note will examine the "in connection with" language of $10 \mathrm{~b}-5$ and the cases which have interpreted that language in order to determine whether $10 \mathrm{~b}-5$ is limited by a transactional requirement.

civil relief under $10 \mathrm{~b}-5$ in order to eliminate the disparity between the liability of sellers and purchasers appears to be a logical extension.

'Mut. Shares Corp. v. Genesco, Inc., 384 F.2d 540, 544 (2d Cir. 1967); Stevens v. Vowell, 343 F.2d 374, 379 (10th Cir. 1965). For an examination of the common law elements of fraud see W. Prosser, The LaW OF TORTS $\$ \S 100-03$ (3d ed. 1964) thereinafter cited as Prosser]. See also Cady, Roberts \& Co., 40 S.E.C. 907, 910 (1961).

${ }^{5} \mathrm{~A}$ few of the sometime conflicting often unartieulated, policy considerations that might influence a court's decision are (1) the court's concern that business executives seemingly innocent of any intentional wrongdoing not be treated under the federal fraud statutes; (2) the court's hesitance to expand federal corporate law; and (3) the court's desire to give the fullest protection to the investing public.

- Compare Freed v. Szabo Food Serv., Inc., CCH FEd. SEC. L. Rep. $\$ 91,317$ (N.D. III. 1964) and Cochran v. Channing Corp., 211 F. Supp. 239, 243-44 (S.D.N.Y. 1962). with Meisel v. North Jersey Trust Co., 218 F. Supp. 274 (S.D.N.Y. 1963). See generally 3 L. Loss. Securities Regulation 1767 (2d ed. 1961) [hereinafter cited as Loss]; Comment, Civil Liability Under Section 1OB and Rule iOB-5: A Suggestion for Replacing the Doctrine of Privily. 74 YALE L.J. 658 (1965).

'See SEC v. Van Horn, 37I F.2d 181 (7th Cir. 1966); Kohler v. Kohler Co., 319 F.2d 634 (7th Cir. 1963); Ellis v. Carter, 291 F.2d 270, 274 (9th Cir. 1961); Texas Continental Life Ins. Co. v. Bankers Bond Co., 187 F. Supp. 14 (W.D. Ky. 1960), rev'd on other grounds sub hom. Texas Continental Life Ins. Co. v. Dunne, 307 F.2d 242 (6th Cir. 1962): Note, Proof of Scienter Necessary in a Private Suil Under SEC Anti-Fraud Rule iOb.5. 63 MiCH. L. Rev. 1070 (1965). But see Weber v. C.M.P. Corp., 242 F. Supp. 321 (S.D.N.Y. 1965); Trussell v. United Underwriters, Ltd., 228 F. Supp. 757 (D. Colo. 1964); cJ. Dack v. Shanman, 227 F. Supp. 26 (S.D.N.Y. 1964).

* See, e.g., Speed v. Transamerica Corp., 99 F. Supp. 808 (D. Del. 1951); Ruder, Civil Liability Under 10b-5: Judicial Revision of Legislative Intent? 57 Nw. U.L. REv. 627, 678 (1963).

- 193 F.2d 461 '(2d Cir.), cert. denied. 343 U.S. 956 (1952).

10193 F.2d at 464. But see McManus v. Jessup \& Moore Paper Co., 5 SEC Jud. Dec. 810 (E.D. Pa. 1948). 


\section{The Birnbaum Purchaser-Seller Doctrine}

The Birnbaum doctrine until recently presented a very significant hurdle to $10 \mathrm{~b}-5$ claimants seeking to question the existence of a transactional requirement. Indeed, the Birnbaum purchaser-seller requirement had been interpreted by later courts as determining the standing of a 10b-5 claimant to bring suit." Under Birnbaum only a person who had been defrauded in connection with his own actual purchase or sale of securities was entitled to 10b-5 relief. The Birnbaum rule, however, has been significantly emasculated under increasing academic, ${ }^{12}$ administrative, ${ }^{13}$ and judicial' ${ }^{14}$ criticism. The Second Circuit itself has hastened the demise of Birnbaum by three recent decisions ${ }^{15}$ which expanded the more traditional meaning of "purchaser" and "seller." These three decisions led one district court to the conclusion that, even though not explicitly overruled by the Second Circuit, Birnbaum no longer

"See, e.g.. Dasho v. Susquehanna Corp., 380 F.2d 262, 269-70 (7th Cir.), cert. denied. 389 U.S. 977 (1967); Greater Iowa Corp. v. McLendon, 378 F.2d 783, 791 (8th Cir. 1967).

${ }^{12}$ See Lowenfels, The Denise of the Birnbaum Doctrine: $A$ New Era for 10b-5, 54 VA. L. Rev. 268 (1968); Comment, The Purchaser-Seller Limitation to SEC Rule 10b-5. 53 CORNell L. Rev. 684 (1968). Professor Loss has suggested that the SEC could adopt rules specifically aimed at the elimination of the Birnbaum doctrine. 3 Loss at 1469 n.87.

For an analysis of the Birnbaum case which suggests that section 10(b) may be read to afford protection for abuses in securities transactions without a limitation of the class of plaintiffs to purchasers or sellers, see Leech, Transactions in Corporate Control, I04 U. PA. L. REv. 725, 832-35 (1956).

13 The SEC, as amicus, in both A.T. Brod \& Co. v. Perlow, 375 F.2d 393, 397 \& n.3 (2d Cir. 1967), and Vine v. Beneficial Fin. Co., 374 F.2d 627, 633 \& n.6, 635 (2d Cir. 1967), argued that the Birnbaum doctrine was a judicially established limitation not necessarily required by the language of section $10(\mathrm{~b})$.

1 Entel v. Allen, 270 F. Supp. 60 (S.D.N.Y. 1967), noted in 42 N.Y.U.L. Rev. 978 (I967). But see Knauff v. Utah Constr. \& Mining Co., 408 F.2d 958, 961 (I0th Cir. 1969).

is A.T. Brod \& Co. v. Perlow, 375 F.2d 393 (2d Cir. 1967) (see note 50 infra and accompanying text); Vine v. Beneficial Fin. Co., 374 F.2d 627 (2d Cir. 1967). In Vine, the plaintiff was allowed standing to bring his suit under I0b-5 even though he had not participated in a securities transaction. Defendant had acquired $95 \%$ of the corporation in which plaintiff was a shareholder. Defendant executed a statutory short-form merger but plaintiff refused defendant's tender. Still holding his shares, plaintiff brought suit alleging a violation of $10 \mathrm{~b}-5$ and the court granted him standing on the grounds that plaintiff, in effect, was a "forced seller" of his securities. Symington Wayne Corp. v. Dresser Indus., Inc., 383 F.2d 840 (2d Cir. I967). In Symington the plaintiffs, minority shareholders of SymingtonWayne, sought to enjoin the defendant's tender offer by alleging certain I0b-5 violations. The court ruled on the merits of the plaintiff's claim without consideration of the standing issue. Clearly the plaintiffs were not purchasers or sellers. Disregarding the eventual refusal to enjoin the defendant's activity, importance should be given to the fact that the court decided the issue on its merits, whereas Birnbaum gave the court ready basis for summary dismissal. 
could be looked upon as restricting the class of $10 \mathrm{~b}-5$ claimants to actual purchasers or sellers. ${ }^{16}$

\section{The Interaction of Sections $3(a)$ and $3(a)(14)$ with Rule 10b-5}

Since the decline of Birnbaum, the more important consideration in examining the possible limitation of $10 \mathrm{~b}-5$ to transactional frauds is the statutory language of sections $3(a)(13)^{17}$ and 3(a)(14). ${ }^{18}$ Section 3(a)(13) defines "purchase" to include any contract to purchase or acquire, and section 3(a)(14) defines "sale" to include any contract to sell or otherwise dispose of. Arguably, when these definitions are read into 10b-5, they require either a binding executory contract for the purchase or sale of securities or a completed purchase or sale before an action is available under the rule. Only a few courts, all at the trial level, have dealt with the question of the necessity of a consummated transaction in 10b-5 actions. In M.L. Lee \& Co. v. American Cardboard \& Packing Corp. ${ }^{19}$ the court upheld the right of a promisee. under an executory contract to bring suit under $10 \mathrm{~b}-5$ for alleged fraud in connection with an aborted contract whereby the promisor had agreed to buy the promisee's capital stock. Although the court phrased the issue in the case as whether $10 \mathrm{~b}-5$ required a consummated purchase or sale, ${ }^{20}$ the court's resolution of the case made it unnecessary to address this issue since such a transaction was in fact found to be present. Relying on sections $3(a)(13)$ and 3(a)(14) as providing the statutory basis for the promisee's action, the court found the existence of an executory contract for the purchase and sale of securities which qualified the transaction

${ }^{16}$ Entel v. Allen, 270 F. Supp. 60, $69-70$ (S.D.N.Y. 1967).

17 U.S.C. $\S 78 \mathrm{c}(\mathrm{a})(13)$ (1964) (emphasis added) provides: "The terms "buy" and 'purchase' each include any contract to buy, purchase, or otherwise acquire."

18 IS U.S.C. $\$ 78 \mathrm{c}(\mathrm{a})(14)(1964)$ (emphasis added) provides: "The terms 'sale' and 'sell' each include any contract to sell or otherwise dispose of."

1936 F.R.D. 27 (E.D. Pa. 1964). Lee involved an underwriter who loaned money to a corporation pursuant to an agreement between the parties whereby the underwriter agreed to buy the corporation's stock prior to its "going public." The underwriter sued the corporation on the loan and the corporation counterclaimed alleging that the underwriter had violated section $10(\mathrm{~b})$ and rule $10 \mathrm{~b}-5$ in that he had refused to perform the contract for the purchase of the corporation's stock. The court's decision is on the plaintiff's motion for dismissal of the counterclaim for failure to state a claim under 10b-5.

${ }^{20}$ The Lee court stated the question raised by the case as being the following: "Does Rule 10b-5 require a consummated purchase or sale for a claim to be asserted on the basis of fraud?" 36 F.R.D. at 30 . 
between the promisee and promisor as a "purchase or sale" within the ambit of the Securities Exchange Act. ${ }^{21}$ The significance of the Lee case, therefore, lies primarily in the court's recognition of the applicability of $3(\mathrm{a})(13)$ and $3(\mathrm{a})(14)$ to section $10(\mathrm{~b})$.

In Goodman v. H. Hentz \& Co., ${ }^{22}$ the court upheld the right of a customer to sue under 10b-5 for damages suffered when a broker "sold" the customer non-existent securities. Even though there could be no completed transaction in such a case, the court reasoned that $10 \mathrm{~b}-5$ proscribed fraud in connection with the purchase or sale of securities and that it would unjustly restrict the phrase "in connection with" if this language were to be applied only to consummated transactions. ${ }^{23}$ Further, reasoning that if the defendant had "perpetrated lesser frauds, such as misrepresentations concerning quality of stocks he recommended . . . or excessive churning of an account to create commissions, "'24 he would have clearly been within the ambit of $10 \mathrm{~b}-5$, the court found it inconsistent to deny the plaintiff $10 \mathrm{~b}-5$ relief because "the fraud was so substantial that [the] entire transaction ... amounted to complete conversions of the [plaintiff's] funds." ${ }^{25}$ The Goodman court, without citing any supporting cases or statutory language other than the "in connection with" language of $10 \mathrm{~b}-5$, was willing to overlook the lack of a completed transaction in securities in order to implement the protections accorded the investing public by section $10(\mathrm{~b})$ and rule $10 \mathrm{~b}-5 . .^{26}$ In contrast to the analysis in the Lee case, the Goodman holding was not centered around the statutory definition of a purchase or sale under 3(a)(13) and 3(a)(14) although a "contract to purchase" was clearly present. The Goodman court apparently found the "in connection with" language of $10 \mathrm{~b}-5^{27}$ to be all that was necessary.

\footnotetext{
${ }^{21}$ Id. at 31 .

2265 F. Supp. 440 (N.D. Ill. 1967).

2 "The court finds no justification in the legislative history of the [Securities Exchange] Act or in the cases for reading this phrase [the "in connection with" phrase of section 10(b)] as if it read merely 'in the purchase or sale' rather than in connection with the purchase or sale." " 265 F. Supp. at 444.

21 Id. at 445.

Id. at 444-45.

${ }^{2 x}$ See notes 52 \& 59 infra.

"See note 23 supra.
} 
Commerce Reporting Co. v. Puretec, Inc. Undermines the 10b-5 Transactional Requirement

Most recently the transactional requirement has been examined by the district court for the Southern District of New York in Commerce Reporting Co. v. Puretec, Inc. ${ }^{28}$ Although an earlier case in the same district had suggested that an aborted contract was an insufficient basis for an action under 10b-5, ${ }^{29}$ the Commerce court explicitly disavowed the prior decision in holding that it is unnecessary to prove a consummated ${ }^{30}$ purchase or sale of securities as a condition to a $10 \mathrm{~b}-5$ action for fraud. ${ }^{31}$

2× 290 F. Supp. 715 (S.D.N.Y. 1968).

2 Keers \& Co. v. Am. Steel \& Pump Corp., 234 F. Supp. 201 (S.D.N.Y. 1964). In Keers, the plaintiffs were minority stockholders bringing suit as aborted sellers or defrauded offerees for the.breach of the majority shareholder's promise not to sell his stock without securing an equally favorable price for the minority shareholders. The promisor died and his executor sold his holdings in breach of the contract. Plaintiffs admitted that, at the time the contract was entered into, the promisor intended to Pulfill his promise. Plaintiffs contended that the fraud arose from the executor's intent not to perform the contract. Although the court in Keers used language that could be interpreted as establishing the rule that aborted sellers and defrauded offerees had no cause of action under $10 \mathrm{~b}-5$ because there was no consummated transaction, see Commerce Reporting Co. v. Puretec, Inc., 290 F. Supp, 715, 718 (S.D.N.Y. 1968), the Keers court qualified its ruling: "Where representations are promissory in nature . . the promisee may not recover unless there is proof that at the time the promises were made the promisor had no intention of keeping them." $234 \mathrm{~F}$. Supp. at 203 (emphasis added). Therefore, the holding in Keers is not that aborted sellers have no 10b5 remedy but rather, in order to come under 10b-5, aborted sellers must allege that there was fraud at the time of entering into the contract. The same restriction as to the necessity of proving fraud at the time of entering into the contract was recognized by the Commerce court. $290 \mathrm{~F}$. Supp. at 720.

${ }^{30}$ There may be some question as to exactly what the commerce court meant when it used the term "unconsummated." Did the court merely mean that there was no closed transaction-no actual transfer of securities-from the seller to the purchaser? If this interpretation is correct an executory contract clearly within the scope of $3(a)(13)$ and $3(a)(14)$ as a purchase or sale would come under question as an "unconsummated" transaction. More likely, the court's use of "unconsummated" referred to a transaction where there was not even a section $3(a)(13)$ and $3(a)(14)$ mutually binding contract for the transfer of securities. Since the express statutory definition of "purchase" and "sale" would be met if such a contract were found, in holding that an unconsummated transaction would also suffice the court must have been directing its attention to something less than a mutually binding contract. Also the proposition that there need not be a ciosed transaction has been recognized for some time, as evidenced by several cases cited in A. BronberG. Securities LAW: FRAUd-SEC RULE 10b-5, \& 8.8, at $221-22$ \& n.98 (1968) [hcreinafter cited as BromBERG], and would not seem subject to question. In this note, therefore, it has been assumed that by "unconsummated" transaction the court meant a transaction that did not meet the statutory definition of a purchase or sale contract under 3(a)(13) and 3(a)(14). See note 32 infra and accompanying text.

II In support of its ruling that a consummated transaction is not needed in order to 
The Facts. The Commerce case involved a claim that Philip and Ronald Purer, principal stockholders of Puretec, lnc., fraudulently entered into an exclusive agency contract ${ }^{32}$ with the Commerce Reporting Company for the sale of Puretec's capital stock with no intention of consummating the transaction with the purchaser secured by Commerce if the Purers received a better offer through their own secret negotiations. Commerce secured Granite Equipment Leasing Company as a purchaser assigning to Granite with the agreement of Puretec the purchase right to Puretec's stock. When the Purers refused to sell to Granite and, in fact, actually sold to VTR, lnc., Commerce brought suit seeking 10b-5 relief. The Purers moved for dismissal contending that the plaintiff failed to meet the dual requirements of rule $10 \mathrm{~b}-5$ in that it did not allege fraud (1) "in connection with" (2) "the purchase or sale" of any

maintain a 10b-5 action for fraud, the Commerce court cites Opper v. Hancock Sec. Corp., 367 F.2d 157 (2d Cir. 1966), and Stockwell v. Reynolds \& Co., 252 F. Supp. 215 (S.D.N.Y. 1965), as well as both Goodman v. H. Hentz \& Co., see notcs 22-27 supra and accompanying text, and M.L. Lee \& Co. v. Am. Cardboard \& Packing Corp., see notes 18-2I supra and accompanying text. Opper involved a suit brought by a customer against a brokerage house for failure to carry out the customer's order to sell certain securities while disposing of large amounts of similar stock held by the brokerage firm. The customer eventually sold the securities at a substantial loss. The Second Circuit, in a per curiam decision, stated: "Failurc to carry out the order while disposing its own similar stock was not only actionable under the contract but also [was] a violation of the Securities Exchange Act." 367 F.2d at 158. Because of the nature of the Second Circuit's consideration of the issue, it is impossible to say on what basis the action was allowed. However, in view of later cases, it would seem safer to say that the court's ruling stands more for the proposition that there is no requirement undcr $10 \mathrm{~b}-5$ that the plaintiff's transaction be simultaneous with the defendant's fraud rather than establishing that no completed transaction was necessary.

Stockwell v. Reynolds \& Co., 252 F. Supp. 215 (S.D.N.Y. 1965), presented a factual situation very similar to that of Opper. In Stockwell the court's decision clearly stood for the proposition that "[s]ection $10(\mathrm{~b})$ and . . . Rule 10b-5 do not require that the purchase or sale immediately follow the alleged fraud." $252 \mathrm{~F}$. Supp. at 219 . It would seem, therefore, that both Opper and Stockwell were cited to support a concept that neither court had considered in the resolution of the cases before them.

${ }^{32}$ The contract betwecn Commerce and the Purers involved the granting of a purchase right option by the Purers to Commerce. Commerce was not obligated to purchase the stock of Puretec but merely had an option to purchase coupled with an exclusive agency contract. The granting of the purchase right option was probably intended to facilitate Commerce's procurement of a purchaser for the Puretec stock. The purchase right option enabled Commerce to act as both principal and agent in obtaining a purchaser for Puretec. $290 \mathrm{~F}$. Supp. at 717. There was no value, see note 47 infra, flowing from Commerce to the Purers for the purchase right option; rather, this option was part of the agency contract. This is not to say that the contract between Commerce and the Purers was illusory. Commerce, as are all exclusive agents, was under an obligation to use its best efforts in obtaining a suitable purchaser for the Puretec stock. See 1 A. Corbin, Contracts § 144, at pp. 623-24 (1963). 
security since the alleged fraudulent agreement was never consummated and therefore amounted to no more than an aborted agreement to sell the stock of Puretec.

The Commerce Rationale. In rejecting the defendant's argument, ${ }^{33}$ the Commerce court looked to the agency transaction between Commerce and the Purers as giving rise to an action for. 10b-5 relief. $^{34}$ Drawing on the Goodman rationale, the court reasoned that to disallow such an action on the original contract between the parties would render meaningless the words "in connection with" and would "artificially restrict the statute to proscription of fraud 'in the purchase or sale' rather than 'in connection with' the purchase or sale of a security.' '35 Pointing to the language used in $A . T$. Brod \& Co. v. Perlow $w^{36}$ and $S E C v$. Capital Gains Research Bureau, Inc., ${ }^{37}$ the court reasoned that Congress' purpose in enacting section 10(b) of the Securities Exchange Act was to protect investors by broadly prohibiting "all fraudulent schemes in connection with the purchase or sale of securities.' 38

The Significance of the Commerce Rationale. The significance of the Commerce decision lies in the court's willingness to uphold a 10b-5 claim founded upon a transaction such as that between Commerce and the Purers, a transaction which involved neither a completed transfer nor a consummated contract to transfer securities. Actually the agreement between Commerce and the Purers was merely a purchase right option arrangement and an exclusive agency contract. ${ }^{39}$ While in form the assignment of a

\footnotetext{
sthough the court did not rule in defendants' favor on the question of whether a cause of action had been stated where there was no consummated transaction, it did dismiss the complaint for being "woefully deficient as to form." 290 F. Supp. at 719. The court's objection was that plaintiff's allegations were "400 skimpy" to satisfy even the lenient "notice" pleading theory of the Federal Rules of Civil Procedurc. 290 F. Supp. at 720. Plaintiff was given leave to amend, however, since the deficiency of the pleading appeared "to be attributable to counsel's oversight rather than his lack of belief in the existence of a factual basis . . . 290 F. Supp. at 720 .

3290 F. Supp. at 718-19.

35 Id. at 718 .

36 375 F.2d 393 (2d Cir. 1967), noted in 1967 DUKE L.J. 894.

375 U.S. 180 (1963).

${ }^{36} 290$ F. Supp. at 718, quoting A.T. Brod \& Co. v. Perlow, 375 F.2d 393, 397 (2d Cir. 1967). The Supreme Court used very similar language and reasoning in SEC v. Capital Gains Research Bureau, lnc., 375 U.S. 180, 195 (1963) (construing the Investment Advisers Act of 1940, 15 U.S.C. $\S 80 \mathrm{~b}-1$ et seq. (1964)).

See note 32 supra.
} 
purchase right to Commerce might be viewed as a contract of sale satisfying the "purchase or sale" definition under 3(a)(13) and $3(a)(14),{ }^{40}$ it was apparently not so treated by the court. If the agency-purchase right contract were itself a statutory purchase or sale, 10b-5 would have been applicable by satisfying the definitional requirements of $3(\mathrm{a})(13)$ and $3(\mathrm{a})(14)$ as a contract. The court, however, found it necessary to utilize the in connection with language to find a $10 \mathrm{~b}-5$ violation in a transaction which took place preliminary to any actual transfer of securities or to the existence of a mutually binding purchase contract.

The Commerce decision leads to two rather radical departures from traditional 10b-5 limitations. First, by holding that a consummated transaction is unnecessary, and not meaning thereby that an executory rather than a completely executed contract will suffice, the Commerce court undermines the transactional requirement of $10 \mathrm{~b}-5$. Since a contract for the purchase or sale of securities is a purchase or sale under the statute, the language "unconsummated transaction" as used by the court must refer to something less than a mutually binding executory contract. By implication, the court's rationale supports the proposition that where a claimant can prove damages, ${ }^{41}$ reliance $^{42}$ and the defendant's fraudulent intent ${ }^{43}$ in connection with dealings ${ }^{44}$ between the parties in contemplation of the transfer of securities, a $10 \mathrm{~b}-5$

${ }^{t 5}$ The cases that have considered the question of what sort of contracts come within the purview of $3(\mathrm{a})(13)$ and (14) are not numerous. Stevens v. Vowell, 343 F.2d 374, 379 (10th Cir. 1965) (contract for the distribution of stock of a corporation to be thereafter formed); Hooper v. Mountain States Sec. Corp., 282 F.2d 195, 202-03 (5th Cir. 1960) (contract for the exchange of stock for capital assets held to be a contract to otherwise "dispose of" securities); H.L. Green Co. v. Childree, 185 F. Supp. 95, 96 (S.D.N.Y. 1960) (under certain circumstances, a contract for the merger of two corporations might involve a purchase and sale of securities). See also New Park Mining Co. v. Cranmer, 225 F. Supp. 261, 267 \& n.5 (S.D.N.Y. 1963).

" 290 F. Supp. at 720 . See note 65 infra.

1290 F. Supp. at 720 . See note 63 infra.

290 F. Supp. at 720.

"While in Commerce the pre-purchase dealings between the Purers and Commerce involved an actual purchase right option and agency contract, it is not clear that only negotiations of this formality will fall within the "in connection with" language. The purchase right option-agency contract, classified by the court as any "unconsummated transaction," consisted of more than unbinding negotiations but less than a mutually binding statutory contract. It remains to be secn whether fraud in preliminary negotiations having no binding effect upon any party will fall within the ambit of $10 \mathrm{~b}-5$ proscription. 
action will stand regardless of whether any actual transaction in securities has taken place.

Secondly, as a direct corollary to the first concept, the Commerce ruling completes the emasculation of the Birnbaum purchaser-seller doctrine. Under the Commerce-Purers agreement Commerce was not a purchaser. The Commerce-Purers agreement gave Commerce a "purchase right," 45 but Commerce at no time received or was obligated to buy Purers stock. The court eschewed the direct approach of finding that the holder of a purchase right was a party to a statutory "contract to purchase" and instead went into the discussion of consummation and the "in connection with" language. Neither did the court treat the transfer of the purchase right from Purers to Commerce as a transfer of "a security, "46 for under this analysis no discussion of consummation would have been relevant since a completed transfer would have occurred. The court apparently did not utilize this approach because the agreement was in substance only an agency arrangement and perhaps because the transfer was not made "for value." 47 Thus, in allowing Commerce,

\footnotetext{
is See note 32 supra.

"Both the 1933 and 1934 acts define a purchase right itself as a security. See 15 U.S.C. 77b(1) (1964); 15 U.S.C. 78c(10) (1964). Arguably the transfer of the purchase right to Commerce would be the sale of a security if this definition were strictly applied. The court, however, did not treat it as such perhaps because it was not given "for value." See note $\mathbf{4 7}$ infra.

17 The only definitional reference to "purchase" and "sale" in the Securities Exchange Act of 1934 is contained in 3(a)(13) and 3(a)(14). See notes 17-18 supra for the language of this section. On the other hand, the Securities Act of 1933 contains a much longer and more detailed definition of "purchase" and "sale." 15 U.S.C. § 77b(3) (1964) reads in part: "The term 'sale' or 'sell' shall include every contract of sale or disposition of a security or interest in a seeurity, for value. The term 'offer to sell,' or 'offer for sale,' or 'offer' shall include every attempt or offer to dispose of, or solicitation of an offer to buy, a security or intcrest in a security, for value. . . " (emphasis added). This section evidences Congress' intent to limit the statutory definition of "purchase" and "sale" to situations where meaningful consideration flows between the parties to a contract for the transfer of securities. Because of the limited attempt to define "purchase" and "sale" in the 1934 Act, it could be argued that Congress expected the more complete definitional section of the 1933 Act to carry over in the application of the 1934 Act. The Supreme Court in Tcherepnin v. Knight, 389 U.S. 332 (1967), indeed recognized that there might be some overlap in the definitional sections of the two acts. Arguably under the 1933 Act definition of purchase and sale the transfer of the purchase right from Purers to Commerce was not given "for value." True, Commerce did promise to use its best efforts in finding a purchaser, but this consideration was given in return for the exclusive agency rather than for the purchase right option which Commerce had no interest in exercising. The purchase right was given merely as a convenience rather than in return for Commerce's efforts as value. While one cannot gratuitously "give" a
} 
a non-purchaser under the court's analysis, to bring this suit, the Commerce court clearly disregarded the limiting influence of Birnbaum.

Only as an alternative holding ${ }^{48}$ does the Commerce court rely on the existence of the later Commerce-Granite contract as being an actual consummated "purchase or sale" connected with the earlier fraud. The court viewed the contract whereby Commerce assigned the purchase right to Granite ${ }^{49}$ as falling within the language of $3(a)(13)$ and $3(a)(14)$ as a contract for the purchase or sale of securities and, therefore, qualifying as a consummated transaction under the traditional purchase-sale definition. If the court had been relying on the cause of action arising from the Purers' fraud as an inducement to the Commerce-Granite contract, the case could have easily been fitted under the approach used by the Second Circuit in A.T. Brod \& Co. v. Perlow. ${ }^{50}$ In Brod the

security as a bonus along with something else that is paid for to take advantage of the "for value" exemption, see H. Bloomenthal, Securities Law 58 (1966), the transaction here was not an attempt to evade the statute but was in substance not a transfer for value at all.

"The Commerce court stated: "The complaint's allegation of the sale and assignment to Granite of the plaintiffs' contract with Purer provides an additional basis for invoking federal jurisdiction based on $\S 10(\mathrm{~b})$ of the Exchange Act." 290 F. Supp. at 719 (emphasis added).

Several traditional approaches under which the holding of the case might be fitted were available to the court. It chose, however, to utilize the Brod method of finding a related fraudulent transaction only in the alternative, and made no use of the fact that the Commerce-Purers transaction might itself be classified as a contract for the purchase and sale of a security, see note 40 supra and accompanying text, or of the possibility of treating the assignment of the purchase right from Purers to Commerce as a completed transfer of a security, sec note 46 supra and accompanying text.

"The Commerce court described the transaction between Commerce and Granite as an "assignment" of the "purchase right" to Granite, a kind of transfor which when made between the Purers and Commerce was viewed as an unconsummated transaction. See notes 30 \& 32 supra. The difference here, however, seems to be that incident to the transfer Granite agreed to exercise the purchase right by transferring 5,000 shares of its common stock to the Purers, and the Purers agreed to accept this as consideration (290 F. Supp. at 717), thus creating a binding contractual arrangement. While this contract was in both form and substance a contract for the purchase or sale of securities, the prior Purers-Commerce transaction was the transfer of a purchase right in form only, while in substance merely an agency arrangement. See note 32 supra and accompanying text.

so 375 F.2d 393 (2d Cir. 1967). In Brod the Second Circuit permitted 10b-5 recovery for a broker who purchased securities for a defendant customer who intended to pay for the shares only if the market price increased before the payment was due. The court found the purchaser-seller requirement satisfied by looking solely to the later consummated transaction-the broker's procurement of the ordered securities. The parallels between the facts of Brod and Commerce raise the question as to why the Commerce court varied from 
Second Circuit looked to the defendants' fraud as the factor that induced the plaintiff to purchase securities. 1t was the plaintiff's procurement of the securities from a third party in reliance upon the defendants' fraud rather than the defendants' order that constituted the "purchase" giving rise to the $10 \mathrm{~b}-5$ violation. If the Commerce court had relied primarily upon this rationale, again there would be no need for its discussion of the non-necessity of a consummated purchase or sale of securities because clearly the binding agreement with Granite satisfied the 3(a)(13) contract requirement.

\section{The Implications of the Commerce Rationale}

The Commerce court, in choosing to grant the cause of action under the more nebulous "in connection with" language, might have been attempting to keep open the judicial door for future suits brought under $10 \mathrm{~b}-5$ in which there was no formal contractual relationship ${ }^{51}$ between the parties but where the facts showed that there was sufficient fraudulent activity "in connection with" the unconsummated negotiations to justify $10 \mathrm{~b}-5$ relief.

In dealing with the unconsummated purchase or sale, the court is defining the limits of $10 \mathrm{~b}-5$ application. To confine $10 \mathrm{~b}-5$ actions to situations where there is a binding contract between the parties

the Second Circuit's rationale in Brod. In both cases, the plaintiffs were aborted offerees; in both, the courts looked not to the original negotiations between the plaintiff and the defendant but rather to the plaintiff's subsequent transaction to determine the measure of damages. Yet the Commerce court did not rely primarily on the subsequent contract between Granite and Commerce as initially giving rise to the $10 \mathrm{~b}-5$ violation. The Brod court avoided the issue of whether the broker would have had an action if he had not procured the securities ordered by the customers. 375 F.2d at $397 \&$ n.3. The approach of the Commerce court would seem to be preferable in that it purports to establish the right of a defrauded party to 10b-5 relief when there is fraud in connection with an unconsummated acquisition or disposition of securities. The existence or non-existence of a subsequent consummated transaction in reliance upon the original representations made between the parties is important only as it goes to prove the damages the plaintiff has suffered. As seen in both the Lee and Goodman cases, see notes 19-27 supra and accompanying text, there may be no subsequent transaction entered into by the plaintiff in reliance on the defendant's fraudulent activity although there is injury. Therefore, it is essential that $10 \mathrm{~b}-5$ plaintiffs have an action on the initial fraudulent activity in order to insure their rights to the protection available under IOb-5.

${ }^{31}$ Admittedly the Commerce-Purers transaction involved a kind of formal contractual arrangement, an option to purchase, but it was substantially less than a mutually binding contract necessary to satisfy the $3(a)(13)$ defimition or the court's definition of consummated purchase. See note 32 supra. 
would unnecessarily exclude factual situations falling in the spirit of 10b-5 investor protection..$^{52}$ On the other hand, it could be said that Congress itself has defined the outer limits of section $10(\mathrm{~b})$ by section $3(a)(13)$ and $3(a)(14),{ }^{53}$ and the courts ought not to extend their jurisdiction to claims not expressly committed to them by Congress. Under this more conservative analysis, $10 b-5$ is applicable only where the claimant can prove a completed transfer or a mutually binding contractual arrangement for the transfer of securities. When the Commerce court departed from the latter view, it broke with the weight of authority in this area. ${ }^{54}$

32 Although the presence of a binding contract for the transfer of securities may serve a very valid evidentiary purpose as to the proof of fraudulent activity, the absence of a contract would not seem to affect the policies of investor protection and maintenance of market stability. Public confidence in the stability of the securities market was one of the gravest concerns of Congress in the passage of section $10(\mathrm{~b})$ of the Securities Exchange Act of 1934. "The idea of a free and open public market is built upon the theory that competing judgments of buyers and sellers as to the fair price of a security brings about a situation where the market price reflects as nearly as possible a just price. Just as artificial manipulation tends to upset the true function of the open market, so the hiding and secreting of important information obstructs the operation of the markets as indices of real value." H.R. REP. No. 1383, 73rd Cong., 2d Sess. 11 (1934) (emphasis added). Why, therefore, limit 10b-5 coverage to those investors who have either closed the transaction or who are under a mutually binding contract for the transfer of securities when there exist other seemingly more * valid 10b-5 limitations on the bringing of bogus claims? See notes 62-65 infra and accompanying text for a discussion of these other limitations.

7. The proposition that the Securities Act of 1933 and the Securities Exchange Act of 1934 should be strictly interpreted by the judiciary so as not to expand these acts into a body of judicially contrived federal corporate law has becn ably espoused by Professor David S. Ruder in several articles. See Ruder, Civil Liability Under Rule 10b-5: Judicial Revision of Legislative Intent? 57 Nw. U.L. REv. 627 (1963); Ruder, Pitfalls in the Development of a Federal Law of Corporations By Implication through Rule lOb-5, 59 Nw. U.L. REV. 185 (1964).

3t Although one of the aims of this note is to point out the seeming inequity of allowing 10b-5 relief to an injured plaintiff who has actually consummated a purchase or sale (i.e., entered into a contract, or. actually completed the transfer) in connection with which the defendant used some "fraudulent scheme" but denying that relief to an injured plaintiff who has only contemplated and perhaps taken preliminary steps toward the consummation of a seeurities transaction, most authority indicates that some completed transaction must have been entered into by the plaintiff before his $10 \mathrm{~b}-5$ claim will be recognized. See, e.g., A.T. Brod \& Co.v. Perlow, 375 F.2d 393 (2d Cir. 1967); Vine v. Beneficial Fin. Corp., 374 F.2d 627 (2d Cir.), cert. denied, 389 U.S. 970 (1967); O'Neill v. Maytag, 339 F.2d 764 (2d Cir. 1964); Birnbaum v. Newport Stecl Corp., 193 F.2d 461 (2d Cir.), cert. denied, 343 U.S. 956 (1952). The necessity for a completed transaction was expressed in M.L. Lee \& Co. v. American Cardboard \& Packing Corp., 36 F.R.D. 27 (E.D. Pa. 1964), in which the court reeognized the applicability of $3(a)(13)$ and $3(a)(14)$ to a situation involving an executory contract for the purchase and sale of securities. The only two cases that question the transactional requirement are Conimierce and Goodman, which are examined in the text. 
Perhaps a hypothetical fact situation could best be used to illustrate the potential reach of the Commerce rationale. Suppose a customer places an order with a brokerage house for 1,000 shares of stock which is then selling for twenty-five dollars per share. The broker assigned to handle the transaction fraudulently induces the customer not to purchase the stock. The customer, relying on the broker's misrepresentation, leaves the office without having purchased any stock through the brokerage house and without giving the broker any compensation for his advice.5 A few months later, the stock is selling for thirty-five dollars per share and the customer brings suit under $10 \mathrm{~b}-5$ alleging the above facts..$^{50}$ Arguably such a situation could come under the Commerce court's interpretation of $10 \mathrm{~b}-5$ as extending relief in a situation involving fraud "in connection with" an unconsummated purchase or sale.57 To allow 10b-5 relief only to those investors who have completed a transaction and not to allow the same relief to those investors who have been fraudulently induced not to complete a transaction would seem to be unjustified discrimination as well as a failure to recognize that by the very language of the Act, fraud in connection

\footnotetext{
ss For the purposes of this hypothetical, the broker is assumed not to receive any direet compensation for his investment advice, but rather receives compensation only from commissions earned on sales. This assumption is necessary in order to keep the problem outside the coverage of $\S 2(6)$ of the Investment Advisers Act of 1940, 15 U.S.C. $\$ 80 \mathrm{~b}-6$ (1964) which provides: "It shall be unlawful for any investment adviser . . . (1) to employ any device, scheme, or artifice to defraud any client or prospective client" (emphasis added). 15 U.S.C. $\$ 80 \mathrm{~b}-2$ (a)(II), however, provides in part: "[This Act] does not include . . . (c) any broker or dealer whose performance of such services [giving investment advice] is solely incidental to the conduct of his business as a broker or dealer and who receives no special compensation therefor . . . ." (emphasis added).

${ }^{50}$ Of course the hypothetical plaintiff could have elected to buy the 1,000 shares upon learning of the defendant's fraud and then brought his action within the traditional. transactional fraud claim under $10 \mathrm{~b}-5$, alleging that defendant's fraud caused plaintiff to delay acquisition of the stock. This alternative, however, would seem to recommend the Conmerce rationale even more. Why should the defrauded investor have to tie up his capital and subject himself to the risks of the securities market in order to bring a suit where he can prove the elements of fraud "in connection with" the unconsummated purchase or sale of seeurities? It would seem to be putting form over substance to require parties such as our hypothetical plaintiff to actually purchase the stock. Also, plaintiffs such as the one in the hypothetical most likely would have invested their money in other securities and, therefore, might not have the funds needed to purchase the stock originally sought.

${ }^{57}$ Clearly, the would-be plaintiff in the above hypothetical does not come within the Birnbaum doctrine but, as has been pointed out (see notes 12-16 supra and accompanying text), this doctrine has been largely eliminated as a limitation not called for under the language of $10 \mathrm{~b}-5$.
} 
wit $h^{58}$ the purchase or sale rather than fraud in the purchase or sale is prohibited. Rule 10b-5 was aimed not only at the prevention of fraud in relation to purchases of securities ${ }^{59}$ but also to prevent fraud that affects the stability of the securities market. ${ }^{60}$ Arguably, fraud that induces an investor not to transact in securities has just as injurious an effect on the stability of the market as does fraud which induces an investor actually to buy or sell securities. The expansion of $10 \mathrm{~b}-5$ to claimants involved in unconsummated transactions would not only provide the fullest measure of investor protection but would increase the number of private actions which operate as a significant economic deterrent to securities fraud. ${ }^{61}$

Of course, the suggestion of this extension of $10 \mathrm{~b}-5$ is likely to raise the counter-argument that many non-purchasing investors would seek to benefit whenever $10 \mathrm{~b}-5$ fraud is uncovered. The opponent of such an extension might point to the innumerable nonpurchasers who might bring suit in the aftermath of a successful 10b-5 action in a situation like that presented in SEC v. Texas Gulf Sulphur $C_{0}{ }^{62}$ in which certain corporate insiders were found guilty

\footnotetext{
sx The Commerce court's reliance on the "in connection with" language to allow a 10b-5 action where no consummated contract existed suggests that this language may be interpreted to refer to activities and negotiations surrounding a contemplated purchase or sale transaction which is never finalized.

59 Presidential Message, S. ReP. No. 792, 73rd Cong., 2d Sess. 1-2 (1934); see Cooper v. North Jersey Trust Co.; 226 F. Supp. 972 (S.D.N.Y. 1964); New Park Mining Co. v. Cranmer, 225 F. Supp. 261 (S.D.N.Y. 1963); Pettit v. Am. Stock Exch., 217 F. Supp. 21 (S.D.N.Y. 1963).

w See note 52 supra.

"I See generally J.1. Case Co. v. Borak, 377 U.S. 426, 432 (1964); Fratt v. Robinson, 203 F.2d 627, 632 (9th Cir. 1953): "[N]othing . . would tend more . . to deter fraudulent practices in security transactions . . . than the right of defrauded sellers or buyers . . to seek redress in damages in federal courts."

${ }_{82} 401$ F.2d 833 (2d Cir. 1968). In TGS the Second Circuit used language which might have some significant bearing on the transactional requirement of $10 \mathrm{~b}-5$. In dealing with the SEC's request for injunctive relief against the corporate defendant's release of public reports containing misrepresentations as to the extent of certain mining discoveries, the court ruled that it was not necessary that the corporation actually transacted in its own securities in order for the court to grant the relief sought. The court stated: "[C]omparisons of Section 10(b) with the antifraud provisions of the Securities Act of 1933 (\$12(2), 15 U.S.C. $\S 77 /(2), \therefore$. [offers or] sells a security by means of . . $\therefore$ \$ $17(\mathrm{a}), 15$ U.S.C. $\$ 77 q(a)$ $\therefore$. in the [offer or] sale of any securities to obtain money or property by means of . . [language in brackets was added in 1954 amendments]), and with the 1936 antifraud amendment of Section 15 of the Securities Exchange Act of 1934 (\$ $15(\mathrm{c})(1), 15$ U.S.C. $\$ 780(c)(1)$. . . effect any transaction in, or to induce or attempt to induce the purchase or sale of, any security ...) denonstrate that when Congress intended that there be a
} 
of $10 \mathrm{~b}-5$ fraud by withholding and understating information concerning an ore discovery. Numerous claimants might allege that they had contemplated purchase of TGS stock but were induced not to purchase by the unfavorable (and fraudulent) statements released by the company's management. The argument, however, can be met by requiring that claimants in situations involving unconsummated transactions carry the substantial burden of proving reliance, ${ }^{63}$ causation, ${ }^{64}$ damage $^{65}$ and that they belong to

participation in a securities transaction as a prerequisite of a violation, it knew how to make that intention clear. . . .

"Therefore it seems clear from the legislative purpose . . . that Congress when it used the phrase 'in connection with a purchase or sale of any security' intended only that the device employed, whatever it might be, be of a sort that would cause reasonable investors to rcly thereon, and, in connection therewith, so relying, cause them to purchase or sell a corporation's securities. There is no indication that Congress intended that the corporations or persons responsible for the issuance of a misleading statement would not violate the section unless they engaged in related securities transactions. . . "Id. at 860 (emphasis added).

The more conservative view of the above quoted language would restrict it to the proposition that a third party-not himself transacting in securities-may incur liability by fraudulent activity which could reasonably be expected to be relied upon to induce others and which in fact does induce others to transact in securities. More broadly construed, the above quoted language might be used to question the necessity of any transaction in securities by anyone where there has been a fraudulent attempt to induce or discourage a purchase or sale. If the defendant engages in fraudulent activity "that would cause reasonable investors to rely thereon, . . . and ... [would] cause them to purchase or sell a corporation's securities," 401 F.2d at 860 (emphasis added), then the defendant is liable for any damages suffered by a plaintiff whether or not such plaintiff has actually transacted in the security. The emphasis is placed on the word "would"; had the court been requiring a transaction by someone, a better choice of words might have been "that [doesl cause them to purchase or scll" securities.

It does not necessarily follow under a liberal interpretation of this language that the fraud must be directed toward inducing a purchase or sale. It would seem that $10 \mathrm{~b}-5$ should likewise be applied to fraud directed at discouraging rather than inducing a purchase or sale, since in both situations no consummated transaction is present, yet the same need for investor protection exists. In view of the nature of the TGS ruling (an action for injunctive relief sought by an administrative agency), perhaps too much should not be read into the court's language, but, at least, the court did question the transactional requirement of $10 \mathrm{~b}-5$ as related to the liability of the defendant.

as Although, as pointed out in note 7 supra and accompanying text, reliance has been dispensed with in certain cases (especially those involving non-disclosure transactions where the transfer was made via a national exchange), reliance still remains a vital limitation of $10 \mathrm{~b}-5$ actions. Reliance has been thought of as essential in direct-dealing non-disclosure cases. See, e.g.. Kohler v. Kohler, 208 F. Supp. 808, 823 (E.D. Wis, 1962), affd, 319 F.2d 634 (7th Cir. 1963). See Bromberg \$ 8.6, at 209-12; 3 Loss 1765-66.

ot Barnet v. Anaconda Co., 238 F. Supp. 766 (S.D.N.Y. 1965). But see Weber v. Bartle, [1966-1967 Transfer Binder] CCH FED. SEC. L. REP. If 91,910 (S.D.N.Y. Mar. 20, 1967). See BromberG $\S 8.7$, at 213-20.

she consideration of damages in relation to an action on an unconsummated purchase or 
the class meant to be influenced by the defendant's activity. ${ }^{66}$ All of these limitations have judicial precedence and could be employed to prevent bogus claims.

Perhaps, in view of the language of 3(a)(13) and 3(a)(14), only a statutory amendment, or continued reliance upon the Brod "related transaction" approach, could effectuate the suggested extension of 10b-5 to cover situations involving unconsummated transactions where the parties have not entered into a mutually binding contract. It would not be unreasonable to anticipate, however, that a court presented with the proper fact situation could rely upon Commerce and Goodman as establishing a right of action under 10b-5 where there has been nothing more than fraud in connection with a contemplated but unconsummated purchase or sale of securities. ${ }^{67}$

sale of securities is very important. If the courts limit recovery by the so-called federal "outof-pocket" measure of actual damages, there would be no recovery for a plaintiff such as the one in the hypothetical. He has suffered no out-of-pocket damages. For an examination of this measure of damages, see Prosser $\S 105$, at 750. Prosser points out, however, that twothirds of the states recognize a "loss-of-bargain" measure of damages in actions for fraud. Id. at 751. The willingness of federal courts to examine all the pertinent circumstances in arriving at a reasonable approximation of tbe damages suffered by plaintiffs claiming $10 \mathrm{~b}-5$ relief seems to lead to the conclusion that the federal courts are not committed to any one concept of damages under 10b-5. Compare Estate Counseling Service, Inc. v. Merrill Lynch, Pierce, Fenner \& Smith, Inc., 303 F.2d 527, 533 (10th Cir. 1962), with Mysel v. Fields, 386 F.2d 718 (8th Cir. 1967) and Ross v. Licht, 263 F. Supp. 395 (S.D.N.Y. 1967). For an examination of the measures of damages under 10b-5, see Ruder, Texas Gulf Sulphur-The Second Round: Privity and State of Mind in Rule lOb-5 Purchase and Sales Cases, 63 Nw. U.L. REv. 423, 427-29 (1968); Note, Measurement of Damages in Private Actions Under Rule lOb-5, 1968 WASH. U.L.Q. 165.

${ }^{6 s}$ At common law, courts have traditionally limited the class of possible claimants for misrepresentation to those whom the defendant had desired to influence in the manner which had occasioned the damages. See ProsSER $\S 102$, at $717 \&$ n.83. This limitation was imposed on actions in deceit for the obvious reason that the class of persons who may have learned of the misrepresentation and were influenced thereby, would be so enormous as to place a burden of liability on the defendant out of proportion to the fault involved. See Keeton, The Ambit of a Fraudulent Representor's Responsibility. 17 TEX. L. Rev. 1 (1938).

${ }^{67}$ A fertile area for use of this theory could be in the derivative suit where corporate directors have "fraudulently" discouraged the corporation from making a purchase or sale for their own selfish ends such as maintaining control or purchasing for their own accounts. See Note, Fiduciary Suits Under Rule 10b-5, 1968 DUKE L.J. 791.

EPILOGUE: It is interesting to note that in SEC v. Nat'1 Sec., Inc., 393 U.S. 453 (1969), the Supreme Court for the first time considered the "purchase and sale" language of 10b-5. The Commission brought suit secking to unwind a merger between two insurance companies where one company had solicited shareholder approval of the transaction by use of material misrepresentations and omissions in violation of $10 \mathrm{~b}-5$. In granting the SEC relief, the Court stated that "[w]hatever the terms 'purchase' and 'sale' may mean in other contexts, here an alleged deception has affected individual shareholders' decisions in a way not at all unlike that involved in a typical cash sale or share exchange. The broad antifraud purposes of the statute and the rule would clearly be furthered by their application to this type of situation." Id. at 467. 
